\title{
POLYCHAETE ASSEMBLAGES IN SW ATLANTIC: RESULTS OF "SHINKAI MARU” IV, V, X AND XI (1978- 1979) CRUISES IN PATAGONIA AND BUENOS AIRES.
}

\author{
ASOCIACIONES DE POLIQUETOS EN EL ATLÁNTICO SW: \\ RESULTADOS DE LAS CAMPAÑAS "SHINKAI MARU” IV, V, X \\ AND XI (1978-1979) EN PATAGONIA Y BUENOS AIRES.
}

Claudia Bremec ${ }^{1}$, Valeria Souto ${ }^{1} \&$ Gabriel Genzano²

\section{RESUMEN}

El objetivo de este trabajo es estudiar la composición de poliquetos en una amplia zona de la plataforma argentina, entre $36^{\circ} \mathrm{S}$ y $55^{\circ} \mathrm{S}$, a partir de muestras colectadas en fondos blandos con rastra Picard, durante las campañas "Shinkai Maru" desarrolladas en 1978-79. Dado que el área de estudio comprende las provincias Biogeográficas Magallánica y Argentina, se analiza si los resultados muestran diferencias en la composición de poliquetos en ambas Provincias. Se estudió un total de 816 individuos; 29 familias, representadas por 70 taxa, fueron identificadas. Las familias más frecuentes (36-57\% estaciones de muestreo) y abundantes fueron Onuphidae, Nephtyidae y Ampharetidae, representadas por Kinbergonuphis dorsalis, Aglaophamus sp. y Ampharete kerguelensis, respectivamente. El Análisis de Agrupamientos, la prueba SIMPER y el ANOSIM mostraron dos conjuntos de especies en dos áreas bien definidas, de acuerdo con un límite aproximado a los $60 \mathrm{~m}$ de profundidad, en correspondencia con las clásicas Provincias Magallánica y Argentina.

Palabras clave: poliquetos bentónicos, fondos blandos, riqueza específica, plataforma continental, Argentina, Provincia Magallánica.

1 Consejo Nacional de Investigaciones Científicas y Técnicas (CONICET)-Instituto Nacional de Investigación y Desarrollo Pesquero (INIDEP). V. Ocampo 1, c.c. 175 (7600) Mar del Plata, Argentina. cbremec@inidep.edu.ar

2 Departamento de Ciencias Marinas, Universidad Nacional de Mar del Plata. Dean Funes 3350 (7600) Mar del Plata, Argentina. 


\begin{abstract}
The aim of this paper is to study the polychaete composition from a wide area in the Argentinean shelf, between $36^{\circ} \mathrm{S}$ and $55^{\circ} \mathrm{S}$, by means of samples collected from soft bottoms with Picard dredge, during the "Shinkai Maru" cruises developed in 1978-79. As the study area comprises both the Magellanic and Argentinean Biogeographic Provinces, we analyze if these results show differences in polychaete composition between both Provinces. A total of 816 individuals was studied; 29 families, represented by 70 taxa, were identified. The most frequent (36-57\% sampling stations) and abundant families were Onuphidae, Nephtyidae and Ampharetidae, mainly represented by Kinbergonuphis dorsalis, Aglaophamus sp. and Ampharete kerguelensis, respectively. Cluster Analysis, SIMPER test and ANOSIM showed two different species assemblages in two well defined areas according to a nearly $60 \mathrm{~m}$ depth boundary, in correspondence with the classical Magellanic and Argentinean Provinces.
\end{abstract}

Key words: continental shelf, Argentina, Magallanic Province.

\section{INTRODUCTION}

Current knowledge on spatial distribution of polychaetes in the Argentine Sea, including shelf areas in Patagonia and Buenos Aires, is related with the sampling effort exerted on different geographical areas (see Elías et al. 2006¹; Bremec $\&$ Giberto 2008). Available information mainly comes from oceanographic cruises developed by research vessels in shelf waters and monitoring in a few coastal localities. The information on species richness of other benthic invertebrate groups reflects a similar state of the art (López Gappa 2000; López Gappa \& Landoni 2005; López Gappa et al. 2006).

The polychaetes from the Argentine continental shelf, a wide area in the southwestern Atlanctic Ocean, have not been exhaustively studied; some papers on structure and distribution of benthic communities in this area excluded polychaetes due to insufficient taxonomic knowledge and consequently, difficulties in identification (Roux et al., 1988; Bastida et al., 1992). Most of the studies developed in the northern shelf (Orensanz 1972a-b; 1973a-b; 1974a-b-c-d; 1975; 1976; Rullier \& Amoureux 1979; SalazarVallejo \& Orensanz 1991; Bremec \& Lana 1994; Bremec \& Giberto 2004; Böggemann \& Orensanz 2007) give information on different polychaete

1 Elías, R., Bremec, C., Lana, P. C. \& J. M. Orensanz. 2006. Historia y perspectivas de los estudios sobre poliquetos del Mar Argentino. 1을 Simposio Latino-Americano de Polychaeta, 3-12 Julio 2006, San Pablo, Brasil: 20. families or assemblages distributed in the Argentine Biogeographic Province. Other papers (Blake 1983; Bremec \& Elías 1999; Hartman 1953; 1966; Hartmann-Schroeder 1983; Hartmann-Schroeder \& Hartmann, 1962; Lana \& Bremec 1994; Orensanz 1974e; 1990; Uschakov 1962; Wesenberg-Lund 1962; Bremec et al. 2000; Elías et al. 2003) mention subantarctic species from the Patagonian shelf (Magellanic Biogeographic Province) and the Strait of Magellan and Antarctica. In general, taxonomical and ecological information on the Strait of Magellan is available in papers produced during the last years (Sanfilippo 1994; Mariani et al. 1996; Gambi \& Mariani 1999; Rozbaczylo et al. 1997; Montiel et al. 2005a, Montiel et al. 2005b).

The aim of this paper is to study the polychaete composition from a wide area in the Argentinean shelf, between $36^{\circ} \mathrm{S}$ and $55^{\circ} \mathrm{S}$, by means of samples collected during the "Shinkai Maru" cruises developed in 1978-79. As the study area comprises both the Magellanic and Argentinean Biogeographic Provinces, we analyze if these results show differences in polychaete composition between both Provinces.

2 Rozbaczylo, N., Ríos, C. \& E. Mutschke. 1997. Poliquetos de la región de Magallanes: estado actual de su conocimiento a través de un análisis histórico y un estudio de caso. Resúmenes del Seminario-Taller Internacional sobre Investigación Biológica Marina en el área de Magallanes en relación con la Antártida, Univ. de Magallanes, Punta Arenas, Chile, 7-11 de abril, 1997: 75. 


\section{MATERIAL AND METHODS}

The biological material was collected in the continental shelf bottoms of Argentina, between $36^{\circ}-55^{\circ} \mathrm{S}$ (Fig. 1) and 44 - 192m water depth. We analyze the polychaete composition in samples taken during the "Shinkai Maru" cruises IV, V, X and XI between $36^{\circ}$ and $50^{\circ} \mathrm{S}$ with Picard dredge from soft bottoms and sieved with $1 \mathrm{~mm}$ mesh screen (Bastida et al. 1992), while information between $50^{\circ}$ and $55^{\circ} \mathrm{S}$ was taken from Bremec et al. (2000), who studied material from the same source. A total of 39 sampling sites, most of them distributed in transects, are herein studied (Table 1). Specimens were fixed in $4 \%$ formaldehyde, preserved in alcohol $70 \%$ and identified at the lowest taxonomic level possible. The information on the composition of the benthic fauna, excluding polychaetes, was obtained in Bastida et al. (1992), while the percentages of occurrence of taxonomic groups ( $\mathrm{N}^{\circ}$ of individuals) were recalculated to show the relative dominance of polychaetes within the total benthic fraction. Cluster Analysis was applied to the Bray-Curtis similarity index assess polychaete assemblages in the study area and Similarity Percentage Analyses (SIMPER) was applied to describe the contribution of species

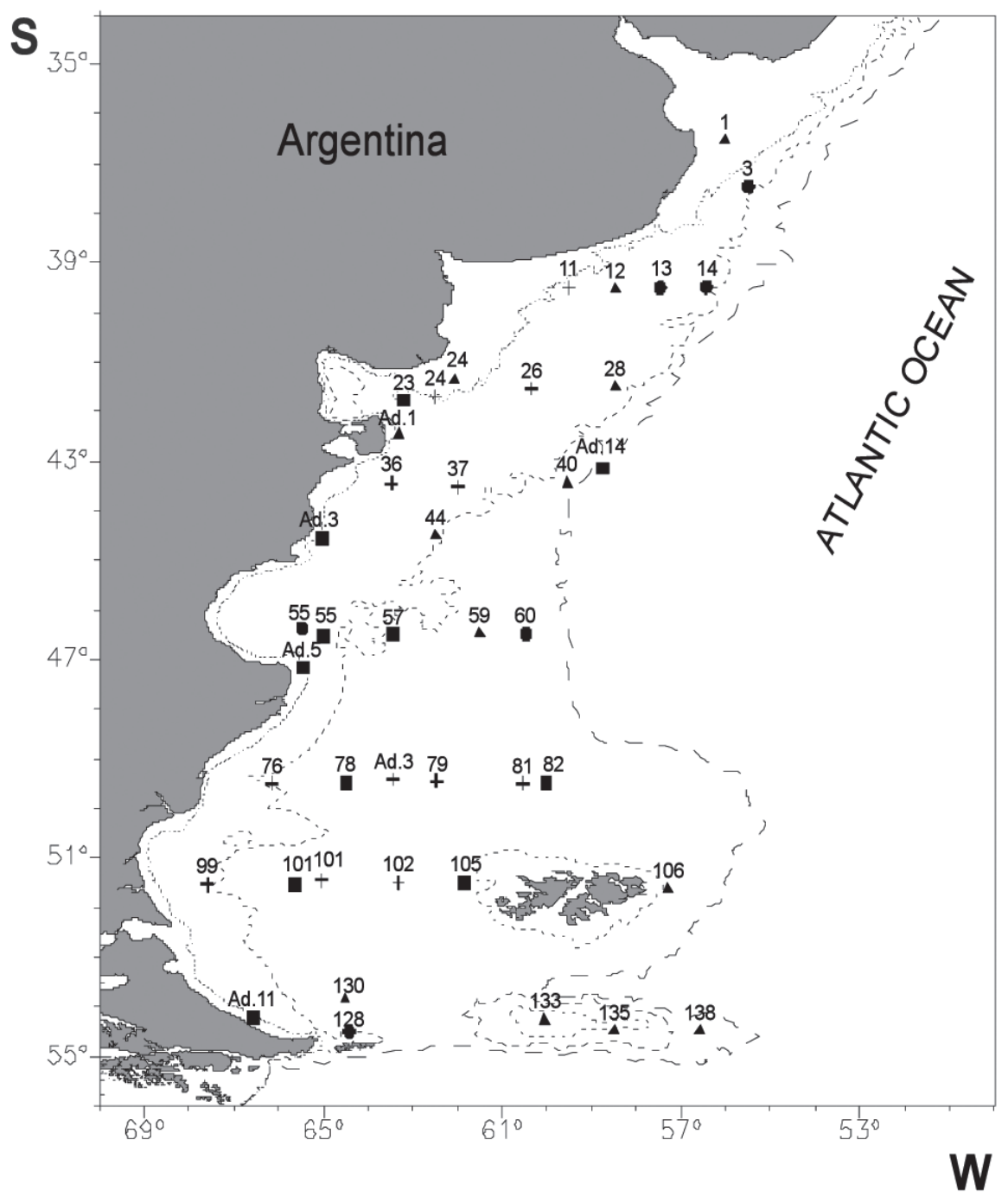

Fig. 1. Location of the sampling stations in Patagonian and Buenos Aires

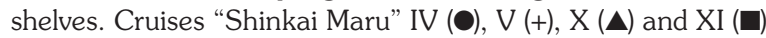


TABLA 1. List of the sampling stations, latitude $\left(\mathrm{S}^{\circ}\right)$, longitude $\left(\mathrm{W}^{\circ}\right)$ and depth $(\mathrm{m})$ in the study area.

\begin{tabular}{|c|c|c|c|c|}
\hline "Shinkain Maru" cruises & Station & Latitude & Longitude & Depth \\
\hline IV & 3 & $37^{\circ} 28^{\prime} 00^{\prime \prime}$ & $55^{\circ} 30^{\prime} 00^{\prime \prime}$ & 80 \\
\hline IV & 13 & $39^{\circ} 30^{\prime} 00^{\prime \prime}$ & $57^{\circ} 28^{\prime} 00^{\prime \prime}$ & 90 \\
\hline IV & 14 & $39^{\circ} 29^{\prime} 00^{\prime \prime}$ & $56^{\circ} 26^{\prime} 00^{\prime \prime}$ & 90 \\
\hline IV & 55 & $46^{\circ} 33^{\prime} 00^{\prime \prime}$ & $65^{\circ} 31^{\prime} 02^{\prime \prime}$ & 79 \\
\hline IV & 128 & $54^{\circ} 30^{\prime} 00^{\prime \prime}$ & $64^{\circ} 25^{\prime} 00^{\prime \prime}$ & 111 \\
\hline IV & 60 & $46^{\circ} 29^{\prime} 00^{\prime \prime}$ & $60^{\circ} 28^{\prime} 00^{\prime \prime}$ & 155 \\
\hline $\mathrm{V}$ & 11 & $39^{\circ} 30^{\prime} 02^{\prime \prime}$ & $59^{\circ} 30^{\prime} 03^{\prime \prime}$ & 60 \\
\hline V & 26 & $41^{\circ} 32^{\prime} 05^{\prime \prime}$ & $60^{\circ} 21^{\prime} 06^{\prime \prime}$ & 67 \\
\hline V & 24 & $41^{\circ} 42^{\prime} 00^{\prime \prime}$ & $62^{\circ} 30^{\prime} 00^{\prime \prime}$ & 50 \\
\hline $\mathrm{V}$ & 36 & $43^{\circ} 27^{\prime} 02^{\prime \prime}$ & $63^{\circ} 28^{\prime} 09^{\prime \prime}$ & 72 \\
\hline $\mathrm{V}$ & 37 & $43^{\circ} 31^{\prime} 00^{\prime \prime}$ & $61^{\circ} 59^{\prime} 05^{\prime \prime}$ & 91 \\
\hline $\mathrm{V}$ & Ad. 3 & $49^{\circ} 25^{\prime} 06^{\prime \prime}$ & $63^{\circ} 26^{\prime} 06^{\prime \prime}$ & 145 \\
\hline V & 76 & $49^{\circ} 30^{\prime} 00^{\prime \prime}$ & $66^{\circ} 09^{\prime} 06^{\prime \prime}$ & 98 \\
\hline V & 79 & $49^{\circ} 27^{\prime} 03^{\prime \prime}$ & $62^{\circ} 28^{\prime} 05^{\prime \prime}$ & 152 \\
\hline V & 99 & $51^{\circ} 32^{\prime} 03^{\prime \prime}$ & $67^{\circ} 35^{\prime} 05^{\prime \prime}$ & 100 \\
\hline V & 101 & $51^{\circ} 29^{\prime} 08^{\prime \prime}$ & $65^{\circ} 32^{\prime} 02^{\prime \prime}$ & 134 \\
\hline V & 102 & $51^{\circ} 30^{\prime} 08^{\prime \prime}$ & $63^{\circ} 10^{\prime} 05^{\prime \prime}$ & 180 \\
\hline V & 81 & $49^{\circ} 30^{\prime} 00^{\prime \prime}$ & $60^{\circ} 32^{\prime} 02^{\prime \prime}$ & 178 \\
\hline $\mathrm{X}$ & 1 & $36^{\circ} 32^{\prime} 00^{\prime \prime}$ & $56^{\circ} 01^{\prime} 00^{\prime \prime}$ & 20 \\
\hline $\mathrm{X}$ & 12 & $39^{\circ} 32^{\prime} 00^{\prime \prime}$ & $58^{\circ} 28^{\prime} 00^{\prime \prime}$ & 83 \\
\hline $\mathrm{X}$ & 24 & $41^{\circ} 30^{\prime} 00^{\prime \prime}$ & $62^{\circ} 31^{\prime} 00^{\prime \prime}$ & 44 \\
\hline $\mathrm{X}$ & 28 & $41^{\circ} 31^{\prime} 00^{\prime \prime}$ & $58^{\circ} 28^{\prime} 00^{\prime \prime}$ & 83 \\
\hline $\mathrm{X}$ & Ad.1 & $42^{\circ} 28^{\prime} 00^{\prime \prime}$ & $63^{\circ} 19^{\prime} 00^{\prime \prime}$ & 56 \\
\hline $\mathrm{X}$ & 40 & $43^{\circ} 27^{\prime} 00^{\prime \prime}$ & $59^{\circ} 32^{\prime} 00^{\prime \prime}$ & 145 \\
\hline$X$ & 44 & $44^{\circ} 30^{\prime} 00^{\prime \prime}$ & $62^{\circ} 29^{\prime} 00^{\prime \prime}$ & 103 \\
\hline $\mathrm{X}$ & 106 & $51^{\circ} 38^{\prime} 00^{\prime \prime}$ & $57^{\circ} 18^{\prime} 00^{\prime \prime}$ & 189 \\
\hline $\mathrm{X}$ & 130 & $54^{\circ} 18^{\prime} 00^{\prime \prime}$ & $64^{\circ} 25^{\prime} 00^{\prime \prime}$ & 161 \\
\hline $\mathrm{X}$ & 133 & $54^{\circ} 16^{\prime} 00^{\prime \prime}$ & $60^{\circ} 03^{\prime} 00^{\prime \prime}$ & 100 \\
\hline $\mathrm{X}$ & 135 & $54^{\circ} 30^{\prime} 00^{\prime \prime}$ & $58^{\circ} 30^{\prime} 00^{\prime \prime}$ & 133 \\
\hline $\mathrm{X}$ & 138 & $54^{\circ} 30^{\prime} 00^{\prime \prime}$ & $56^{\circ} 35^{\prime} 00^{\prime \prime}$ & 135 \\
\hline $\mathrm{X}$ & 59 & $46^{\circ} 28^{\prime} 00^{\prime \prime}$ & $61^{\circ} 30^{\prime} 00^{\prime \prime}$ & 121 \\
\hline XI & 82 & $49^{\circ} 28^{\prime} 00^{\prime \prime}$ & $60^{\circ} 28^{\prime} 00^{\prime \prime}$ & 188 \\
\hline XI & 55 & $46^{\circ} 31^{\prime} 00^{\prime \prime}$ & $65^{\circ} 27^{\prime} 00^{\prime \prime}$ & 72 \\
\hline XI & 57 & $46^{\circ} 30^{\prime} 00^{\prime \prime}$ & $63^{\circ} 26^{\prime} 00^{\prime \prime}$ & 115 \\
\hline XI & Ad.3 & $44^{\circ} 34^{\prime} 00^{\prime \prime}$ & $65^{\circ} 01^{\prime} 00^{\prime \prime}$ & 82 \\
\hline XI & Ad. 5 & $47^{\circ} 04^{\prime} 00^{\prime \prime}$ & $65^{\circ} 27^{\prime} 00^{\prime \prime}$ & 70 \\
\hline XI & 78 & $49^{\circ} 29^{\prime} 00^{\prime \prime}$ & $64^{\circ} 29^{\prime} 00^{\prime \prime}$ & 120 \\
\hline XI & Ad.14 & $43^{\circ} 33^{\prime} 00^{\prime \prime}$ & $59^{\circ} 50^{\prime} 00^{\prime \prime}$ & 116 \\
\hline XI & 23 & $41^{\circ} 46^{\prime} 00^{\prime \prime}$ & $63^{\circ} 13^{\prime} 00^{\prime \prime}$ & 65 \\
\hline XI & 101 & $51^{\circ} 24^{\prime} 00^{\prime \prime}$ & $65^{\circ} 29^{\prime} 00^{\prime \prime}$ & 135 \\
\hline XI & 105 & $51^{\circ} 29^{\prime} 00^{\prime \prime}$ & $61^{\circ} 50^{\prime} 00^{\prime \prime}$ & 192 \\
\hline $\mathrm{XI}$ & Ad.11 & $54^{\circ} 13^{\prime} 00^{\prime \prime}$ & $66^{\circ} 33^{\prime} 00^{\prime \prime}$ & 55 \\
\hline
\end{tabular}

to the dissimilarity between groups of stations. The Analysis of Similarities (ANOSIM) was carried out between samples located in the Argentinean (less than $\sim 60 \mathrm{~m}$ depth, stations SMV 11 and 24, SMX 1, 24 and Ad1, SMXI 23) and Magellanic Provinces (rest of stations) (Seminario sobre biogeografía de los organismos marinos 1964, Boschi 2000) to analyze polychaete distribution patterns, considering the null hypothesis of no differences between Provinces. We used PRIMER version 6.1 (Clarke \& Gorley 2006) with transformed (fourth root) abundance and presence-absence data, excluding unique findings. 


\section{RESULTS}

The relative dominance ( ${ }^{\circ}$ of individuals) of polychaetes in the samples collected in the Argentinean shelf was 12.3\% (816 individuals), after molluscs (43.7\%), crustaceans (23.2\%) and echinoderms (20.7\%). The total number of families identified was 29 (Table 2, Fig. 2). The most frequent (36-57\% stations) and abundant families were Onuphidae, Nephtyidae and Ampharetidae, mainly represented by Kinbergonuphis dorsalis (Ehlers, 1897), Aglaophamus sp. and Ampharete kerguelensis (McIntosh, 1885) respectively. Polychaetes were represented by 70 taxa, 35 of them identified at species level (Table 2). The total number of taxa with unique presence was 31 , and 24 of them were identified at generic or family level.

Both cluster analyses among sites show one group of sampling stations with the presence of species largely distributed in the Patagonian and Buenos Aires

TABLE 2: List of the polychaete taxa found in the study area (Unid= Unidentified).

\begin{tabular}{|c|c|}
\hline FAMILY & SPECIES \\
\hline EUPHROSINIDAE & Euphrosine armadilloides Ehlers, 1900 \\
\hline APHRODITIDAE & Aphrodita longicornis Kinberg, 1855 \\
\hline \multirow[t]{2}{*}{ POLYNOIDAE } & Harmothoe sp. 1 \\
\hline & Harmothoe sp. 2 \\
\hline SIGALIONIDAE & Sigalionidae unid. \\
\hline \multirow[t]{4}{*}{ GLYCERIDAE } & Glycera americana Leidy, 1855 \\
\hline & Glycera capitata Orsted, 1842 \\
\hline & Glycera sp. \\
\hline & Hemipodus sp. \\
\hline GONIADIDAE & Glycinde sp. \\
\hline \multirow[t]{3}{*}{ PHYLLODOCIDAE } & Paranaitis sp. \\
\hline & Phyllodoce patagonica (Kingberg, 1866) \\
\hline & Phyllodocidae unid. \\
\hline \multirow[t]{2}{*}{ NEREIDIDAE } & Eunereis patagonica (McIntosh, 1885) \\
\hline & Nereididae unid. \\
\hline \multirow[t]{4}{*}{ SYLLIDAE } & Syllis (Syllis) magellanica Augener, 1918 \\
\hline & Syllis (Langerhansia) anops Ehlers, 1897 \\
\hline & Syllis sp. \\
\hline & Typosyllis sp. \\
\hline \multirow[t]{3}{*}{ NEPHTYIDAE } & Aglaophamus sp. \\
\hline & Nephtys magellanica Augener, 1912 \\
\hline & Nephtys sp. \\
\hline \multirow[t]{2}{*}{ EUNICIDAE } & Eunice pennata (O. F. Muller, 1776) \\
\hline & Eunice magellanica McIntosh, 1885 \\
\hline \multirow[t]{2}{*}{ ONUPHIDAE } & Kinbergonuphis dorsalis (Ehlers, 1897) \\
\hline & Nothria anoculata Orensanz, 1974 \\
\hline \multirow[t]{3}{*}{ OENONIDAE } & Drilonereis tenuis (Ehlers, 1901) \\
\hline & Notocirrus lorum Ehlers, 1897 \\
\hline & Notocirrus virginis (Kinberg, 1865) \\
\hline \multirow[t]{2}{*}{ LUMBRINERIDAE } & Lumbrineris cingulata (Ehlers, 1897) \\
\hline & Lumbrineris sp. \\
\hline CHAETOPTERIDAE & Phyllochaetopterus socialis platensis Hartman, 1953 \\
\hline SPIONIDAE & Spiophanes sp. \\
\hline \multirow[t]{3}{*}{ ORBINIIDAE } & Phylo felix Kinberg, 1866 \\
\hline & Scoloplos sp. \\
\hline & Orbiniidae unid. \\
\hline CIRRATULIDAE & Cirratulidae unid. \\
\hline FLABELLIGERIDAE & Piromis capitata (Nonato, 1966) \\
\hline
\end{tabular}




\section{PARAONIDAE \\ OPHELIIDAE}

SCALIBREGMATIDAE

MALDANIDAE

\section{AMPHARETIDAE}

TEREBELLIDAE

TRICHOBRANCHIDAE

SABELLARIIDAE

SABELLIDAE
Paraonidae unid.

Ophelina gymnopyge (Ehlers, 1908)

Ophelina scaphigera (Ehlers, 1901)

Ophelina syringopyge (Ehlers, 1901)

Armandia sp.

Euzonus sp.

Travisia kerguelensis McIntosh, 1885

Travisia olens Ehlers, 1897

Lumbriclymenella robusta Arwidsson, 1911

Rhodine antarctica Gravier, 1907

Euclymene sp.

Nicomache sp.

Euclymeninae unid.

Lumbriclymeninae unid.

Maldanidae unid. 1

Maldanidae unid. 2

Ampharete kerguelensis (McIntosh, 1855)

Melinna cristata (Sars, 1851)

Ampharetidae unid.

Pista corrientis McIntosh, 1885

Thelepinae unid.

Terebellidae unid.

Terebillides malvinensis Bremec \& Elías, 1999

Idanthyrsus macropaleus (Schmarda, 1861)

Perkinsiana antarctica (Kinberg, 1867)

Euchone sp.

Perkinsiana sp.

Fabriciinae unid.

Sabellinae unid.1

Sabellinae unid. 2

Serpula narconensis Baird, 1865

Owenia tegula (Kinberg, 1867)

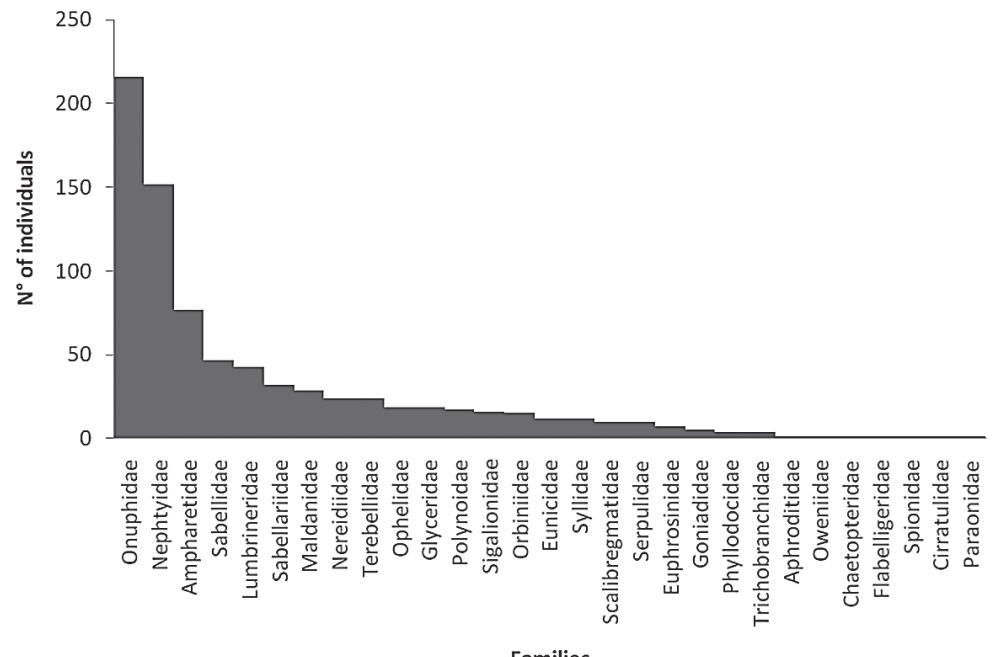

Fig. 2. Polychaete families identified in the Argentinean shelf during this study. Bars indicate the number of individuals. 


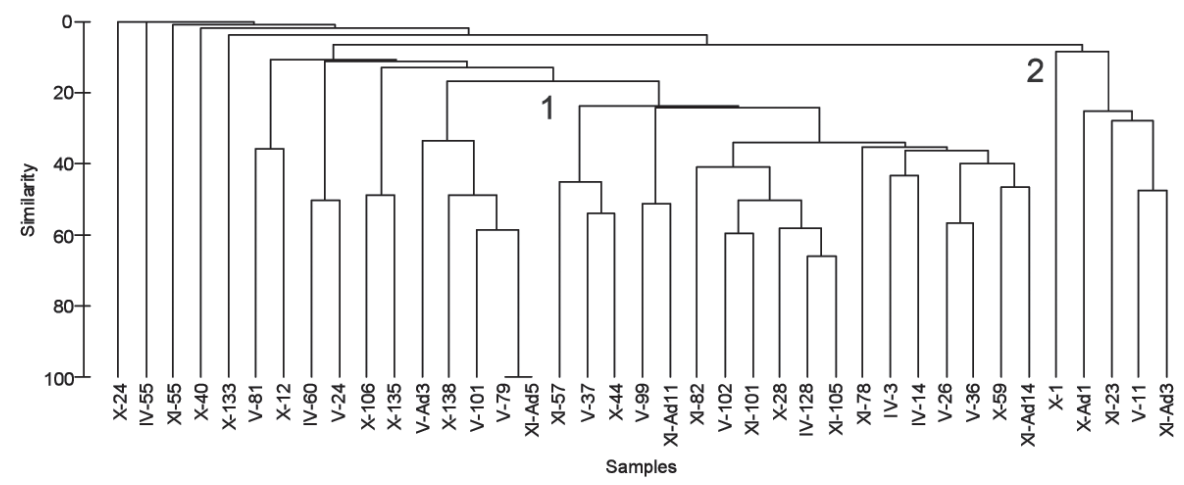

B

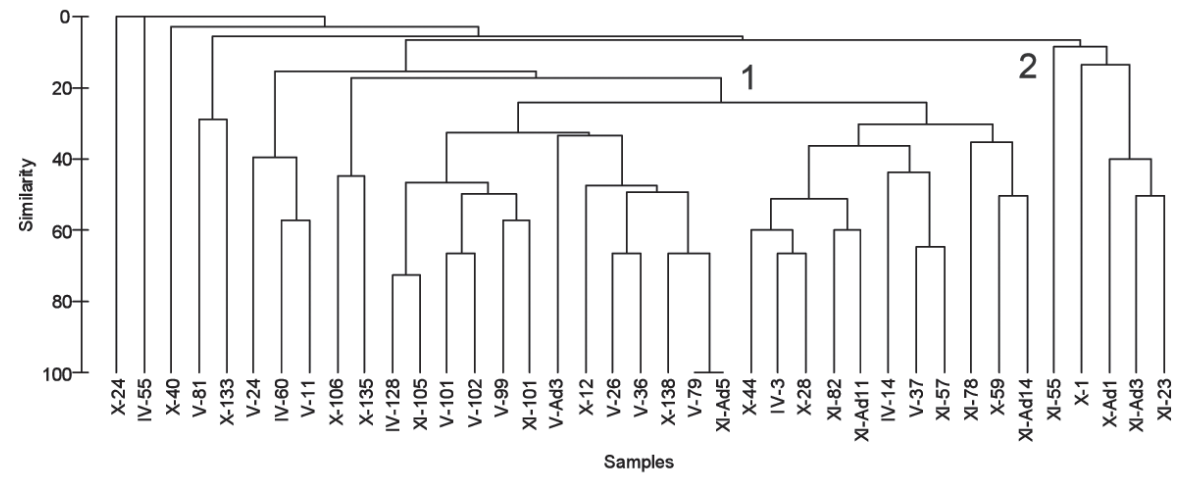

Fig. 3. Dendrograms among sampling stations in the Argentinean shelf during this study. Abundance data (A), Presence-Absence data (B).

shelves (Fig. $3 \mathrm{~A}$ and B, group 1). Coastal stations were clustered in separate groupings (Fig. $3 \mathrm{~A}$ and B, group 2) or showed lower similarity (stations 24 and 55). The SIMPER test (presence-absence data) resulted in an average dissimilarity $=94.71 \%$ between both groups. K. dorsalis, Aglaophamus sp., A. kerguelensis, Perkinsiana antarctica (Kinberg, 1867), Idanthyrsus macropaleus (Schmarda, 1861) and Travisia kerguelensis McIntosh, 1885 contributed $88 \%$ to the average similarity of group 1 (= $32 \%)$. The species Eunice pennata (O.F. Muller, 1776), Harmothoe sp.1, Glycera americana Leidy, 1855 and Drilonereis tenuis (Ehlers, 1900) contributed $91 \%$ to the average similarity of group 2 (= 14\%). The results of the ANOSIM analysis between stations from Argentinean and Magellanic Provinces (Global $\mathrm{R}=0.334 ; \mathrm{p}=0.01$ ) lead to the rejection of the null hypothesis and show differences in the polychaete species composition.

\section{DISCUSSION}

This study gives faunistic information on benthic assemblages from a wide geographical area in the SW Atlantic, between $36^{\circ}$ and $55^{\circ} \mathrm{S}$. The relative abundance of polychaetes ( $n^{\circ}$ of individuals) within the benthic fraction herein analyzed did not reach a high average value (12\%) for the whole study area. Previous studies indicate noticeable differences between southern Patagonian shelf and Straits of Magellan, where 9\% and 35-67\% in dominance of polychaetes were estimated respectively (Gambi \& Mariani 1999, Bremec et al. 2000, Thatje \& Brown 2009). This data show that polychaetes have a relatively limited quantitative importance in the soft bottoms of the study area, although they are expected to be an abundant taxon in this type of substrate (Knox \& Lowry 1977, Hutchinson 1998). Regarding the number of taxa found in ecological 
surveys developed with the same sampling device in the study area, the contribution of polychaetes is neither dominant. The taxa herein identified represent $13 \%$ of the mollusk, echinoderm, bryozoan (Bastida et al. 1992) and polychaete species (this study) collected during "Shinkai Maru" cruises. Similar results were obtained by Roux et al. (1993) and Sánchez et al. (2010) in areas between $38^{\circ} \mathrm{S}$ and $44^{\circ} \mathrm{S}$ and 38 to $218 \mathrm{~m}$ depth, in which polychaetes conformed $16-19 \%$ of the collected species.

The polychaete species richness in our study developed in Atlantic waters was 72. Historical information on polychaete taxonomic research for the Pacific and Atlantic Magellan region gives a total of 431 species, from which 25\% occurred as single findings and the most speciose family was Syllidae (Montiel et al. 2005). In the present sampling, nearly half of the taxa collected were unique records and the higher species richness corresponded to Maldanidae (8 taxa, see Table 2), while the most abundant families were less diversified: Onuphidae, Nephtyidae and Ampharetidae. The frequent group of species, mainly represented by Kinbergonuphis dorsalis, Aglaophamus sp. and Ampharete kerguelensis, were largely distributed in the whole study area. They come from samples collected at more than $70 \mathrm{~m}$ depth (with the exception of station $\mathrm{Ad} 11,55 \mathrm{~m}$ depth, located at Tierra del Fuego, see Figs. 1 and 3) together with other three well represented species: Perkinsiana antarctica, Idanthyrsus macropaleus, Travisia kerguelensis. Sediment composition on the continental shelf is dominated by sands and silts $<2 \mathrm{~mm}$, at depths between 50 and 200m (Bastida et al. 1981, 1992). The present sampling area is homogeneous when compared with the other Magellanic habitats, channels and fjords on the Pacific $\left(42^{\circ} \mathrm{S}-55^{\circ} \mathrm{S}\right)$ and the Straits of Magellan (52 $58^{\prime}-53^{\circ} 43^{\prime} \mathrm{S}$ and $70^{\circ} 55^{\prime}-$ $\left.70^{\circ} 71^{\prime} \mathrm{W}\right)$, both with heterogeneous and patchy types of sediments (see Montiel et al. 2005). Environmental differences, i.e higher habitat diversity and wider depth range, favours the higher dominance and diversity of austral species when compared with the homogeneous habitats sampled in Patagonia (Mariani et al. 1996; Gambi \& Mariani 1999, Bremec et al. 2000, Montiel et al. 2005) and Buenos Aires shelves. The group of stations between $36^{\circ}-47^{\circ} \mathrm{S}$ and $44-65 \mathrm{~m}$ depth (see Figs. 1 and 3) was characterized by species of different families than those above referred: Eunice pennata, Harmothoe sp.1, Glycera americana and
Drilonereis tenuis. The sediments in these areas are composed by a coarse fraction $>2 \mathrm{~mm}$ that prevails near the coast, at depths lower than 50m (Bastida et al. 1981, 1992). Only G. americana was known from Brazil to Golfo Nuevo ( $\left.43^{\circ} \mathrm{S}\right)$; both $D$. tenuis and E. pennata were previously recorded in subantarctic waters (Orensanz 1990; Orensanz et al. in prep.). Shallower and more samples are needed in order to properly characterize the faunal components in the Argentine Province.

These results show the presence of different assemblages in the two mentioned areas and are, in general, in agreement with the ANOSIM developed between stations located at the classical Magellanic and Argentinean Provinces (see Seminario sobre biogeografía de los organismos marinos 1964, Boschi 2000, López Gappa 2000). It must be pointed out that although nearly $60 \mathrm{~m}$ depth was considered in this study to sort the sampling stations for the ANOSIM, the limits of these provinces are difficult to establish (see Boschi, 2000). In this study, both abundance and presence of the species defined the clusters of stations. Unique presences were excluded in this analysis, and hence developed with 38 taxa; however the significant difference between them was revealed, as well as the affinities of the deeper area with the polychaete fauna that characterizes the Atlantic side of the tip of South America, Magellanic subregion suggested by Montiel et al. (2005). The present results also indicate the presence of the same abundant assemblage of species in soft bottoms of middle and deep shelf, extending northwards at least at $36^{\circ} \mathrm{S}$.

Regarding the more coastal area (selected as Argentine Province in this study), these analyses show affinities of the stations distributed between $36^{\circ} \mathrm{S}$ and reaching nearly $47^{\circ} \mathrm{S}$ (station 55); this latitude exceeds the general scheme that indicates faunal transition at $42^{\circ}-43^{\circ} \mathrm{S}$. Although the number of locations sampled at lower depths, between 44 and $65 \mathrm{~m}$, is scarce, we stress out the significant differences between the areas herein recognized. Moreover, it was carried out with biological material sampled with the same dredge and spatially distributed in transects, in order to cover the study area as regularly as possible. Future studies considering historical data of polychaete taxonomy in the Argentine Province, and transitional zones of distribution, like Peninsula Valdés $\left(42^{\circ} \mathrm{S}\right)$ and the 
Río de la Plata estuary $\left(35^{\circ} \mathrm{S}\right)$, deserve detailed study in the case of polychaetes. In example, species of Sabellaria well known for Brazilian localities, were recorded in Buenos Aires waters, although the latter zone was considered a zoogeographical barrier in the distribution of marine fauna between Brasil and Argentina (Bremec \& Giberto 2004).

\section{ACKNOWLEDGEMENTS}

We are indebted to Dr. R. Bastida (University of Mar del Plata, Argentina) and Dr. A. Roux (INIDEP, Argentina) for material collected during "Shinkai Maru" cruises. We greatly appreciate taxonomic help to Dr. J. M. Orensanz, who identified Sigalionids. Finantial support INIDEP, CONICET, PICT 2007-02200. This is INIDEP Contribution $N^{\circ} 1626$. We thank three anonymous reviewers for improving the MS.

\section{LITERATURE CITED}

Bastida, R., C. Urien, V. Lichtschein, A. Roux \& P. Arias 1981. Investigación sobre comunidades bentónicas. Características generales del sustrato (Campañas IV, V, X y XI del B/I "Shinkai Maru"). Contribuciones Instituto Nacional Investigación Desarrollo pesquero 383: 318-339.

Bastida, R., A. Roux \& D. Martínez 1992. Benthic communities of the Argentine continental shelf. Oceanologica Acta 15 (6): 687-698. Blake, J. 1983. Polychaetes of the Family Spionidae from South America, Antarctica, and adjacent seas and islands. Antarctic Research Series 29: 205-288.

Böggemann, M. \& J.M. Orensanz 2007. Glyceriformia Fauchald, 1977 (Annelida: Polychaeta) from the SW Atlantic Shelf, between $30^{\circ}$ and $45^{\circ}$ S. Mitteilungen aus dem Hamburgischen Zoologischen Museum und Institut 104:11-59.

Boschi, E. 2000. Species of decapod crustaceans and their distribution in The American Marine Zoogeographic Provinces. Revista de Investigación y Desarrollo Pesquero 13: 7-136.

Bremec C. \& P.C. Lana 1994. New records of Sabellariidae (Annelida: Polychaeta) from Argentina. Neritica 8 (1-2): 47-53.
Bremec, C. \& R. Elias 1999. Terebellides species (Polychaeta, Trichobranchidae) in cold-temperate waters from Southwestern Atlantic Ocean. Ophelia 3: 177-186.

Bremec, C., R. Elias \& M.C. Gambi 2000. Comparison of polychaete community composition from the patagonian shelf and Strait of Magellan, preliminary results from cruises "Shinkai Maru" IV, V, X and XI (1978-1979) and 2nd. P.N.R.A. Oceanographic Cruise (1991). Bulletin of Marine Science 67 (1): 189-197.

Bremec, C. \& D. Giberto 2004. New records of two species of Sabellaria (Polychaeta, Sabellariidae) from the Argentinean Biogegraphic Province. Revista de Biología Marina y Oceanografía 39(2): 101-105.

Bremec, C. \& D. Giberto 2008. Poliquetos. En: Atlas de sensibilidad ambiental de la Costa y el Mar Argentino (D. Boltovskoy, ed.) Proyecto "Prevención de la Contaminación Costera y Gestión de la Diversidad Biológica Marina" (GEF, BM, PNUD, SAyDS), componente "Conservación de la Diversidad Biológica y Prevención de la Contaminación Marina en Patagonia" (Proy. ARG 02/018). Publicación On-line www.ambiente.gov.ar.

Clarke, K.R. \& R.N. Gorley 2006. PRIMER v6: User Manual/Tutorial. PRIMER-E, Plymouth 190pp. Elías, R., Bremec, C., Lana, P. C. \& J.M. Orensanz 2003. Opheliidae (Polychaeta) from the southwestern Atlantic Ocean. Hydrobiologia, The Netherlands 496: 75-85.

Gambi, M.C. \& S. Mariani 1999. Polychaetes of the soft bottoms of the Straits of Magellan collected during the italian oceanographic cruise in february-March 1991. Scientia Marina 63 (Supl. 1): 233-242.

Hartman, O. 1953. Non-pelagic polychaetes of the Swedish Antarctic Expedition. 1901-1903. Further Zoological Results of the Swedish. Antarctic Expeditions 4 (11): 1-83.

Hartman O. 1966. Polychaeta Myzostomidae and Sedentaria of Antarctica. Antarctic Research Series 7: 1-158 pp.

Hartmann-Schroeder, G. 1983. Die Polychaeten der 15., 36. und 76. Reise von FFS "Walther Herwig" zum patagonischen Schelf (SüdwestAtlantik). Senckenbergiana maritima 15 (4/6): 251-277. 
Hartmann-Schroeder, G. \& G. Hartmann 1962. Zur Kenntnis des Eulitorals der chilenischen Pazifikküste und der argentinischen Küste Südpatagoniens unter besonderer Berücksichtigung der Polychaeten und Ostracoden. Mitteilungen aus dem Hamburgischen Zoologischen Museum und Institut 1-270.

Hutchinson, P. 1998. Biodiversity and functioning of polychaetes in benthic sediments. Biodiversity Conservation 7: 1133-1145.

Knox, G. \& K. Lowry 1977. A comparison between the benthos of the Southern Ocean and the North Polar ocean with special reference to the Amphipoda and Polychaeta. In: M. J. Dunbar (ed.) Polar Ocean: 423-462. Arctic Institute of North America, Calgary.

Lana, P.C. \& C. Bremec 1994. Sabellariidae (Annelida, Polychaeta) from South America. Mémories du Muséum National d'Histoire Naturelle 162: 209-221.

López Gappa, J.J. 2000. Species richness of marine Bryozoa in the continental shelf and slope off Argentina (south-west Atlantic). Diversity and Distributions 6: 15-27.

López Gappa, J.J. \& N. Landoni 2005. Biodiversity of Porifera in the Southwest Atlantic between $35^{\circ} \mathrm{S}$ and $56^{\circ} \mathrm{S}$. Revista del Museo Argentino de Ciencias Naturales 7(2): 191-219.

López Gappa, J. J., G.M. Alonso \& N. Landoni 2006. Biodiversity of benthic Amphipoda (Crustacea: Peracarida) in the Southwest Atlantic between $35^{\circ} \mathrm{S}$ and $56^{\circ} \mathrm{S}$. Zootaxa 1342: 1-66.

Mariani, S., M.C. Gambi, M. Lorenti \& L. Mazzella 1996. Benthic populations of the soft bottoms in the Strait of Magellan (Southern America): biodiversity, distribution and biogeography of polychaetes and crustacean isopods. Biologia Marina Mediterranea 3 (1): 155-158.

Montiel, A., D. Gerdes, B. Hilbig \& W.E. Arntz 2005. Polychaete assemblages on the Magellan and Weddell Sea shelves: comparative ecological evaluation. Marine Ecology Progress Series 297: 189-202.

Montiel, A., D. Gerdes \& W. Arntz 2005. Distributional patterns of shallowwater polychaetes in the Magullan region: a zoogeographical and ecological sinopsis. Scientia Marina 69 (Suppl. 2): 123-133.
Orensanz, J.M. 1972a. Los anélidos poliquetos de la Provincia Biogeográfica Argentina. I. Palmyridae (=Chrysopetalidae), Amphinomidae y Euphrosinidae. Physis 31 (83): 485-501.

Orensanz, J.M. 1972b. Los anélidos poliquetos de la Provincia Biogeográfica Argentina. II. Aphroditidae. Physis 31 (83): 503-518.

Orensanz, J.M. 1973a. Los anélidos poliquetos de la Provincia Biogeográfica Argentina. III. Dorvilleidae. Physis 32 (85): 325-342.

Orensanz, J.M. 1973b. Los anélidos poliquetos de la Provincia Biogeográfica Argentina. IV. Lumbrineridae. Physis 32 (85): 343-393.

Orensanz, J.M. 1974a. Los anélidos poliquetos de la Provincia Biogeográfica Argentina. V. Onuphidae. Physis 33 (86): 75-122.

Orensanz, J.M. 1974b. Los anélidos poliquetos de la Provincia Biogeográfica Argentina. VI. Arabellidae. Physis 33 (87): 381-408.

Orensanz, J.M. 1974c. Poliquetos de la Provincia Biogeográfica Argentina. VIII. Polygordidae. Neotropica 20 (62): 87-91.

Orensanz, J.M. 1974d. Poliquetos de la Provincia Biogeográfica Argentina. X. Acrocirridae. Neotropica 20 (63): 113-119.

Orensanz, J.M. 1974e. Los anélidos poliquetos de la Provincia Biogeográfica Magallánica. I.Catálogo de las especies citadas hasta 1974. Lab. Comunidades Bentónicas, Gabinete Abierto, Santa Clara del Mar, Argentina, Contribución Técnica 1: 83 pp.

Orensanz, J.M. 1975. Los anélidos poliquetos de la Provincia Biogeográfica Argentina. VII. Eunicidae y Lysaretidae. Physis 34 (88): 85-111.

Orensanz, J.M. 1976. Los anélidos poliquetos de la Provincia Biogeográfica Argentina. IX. Poecilochaetidae y Cossuridae. Comunicaciones Zoológicas del Museo de Historia Natural de Montevideo X (140): 1-11.

Orensanz, J.M. 1990. The Eunicemorph polychaet annelids from Antarctic and Subantarctic Seas. Biology of the Antarctic Seas XXI. Antarctic Research Series 52: 1-183.

Roux, A., R. Bastida, V. Lichtschein \& A. Barreto 1988. Investigaciones sobre las comunidades bentónicas de plataforma a través de una transecta frente a Mar del Plata. Spheniscus 6: $19-52$. 
Roux, A., R. Bastida \& C. Bremec 1993. Comunidades bentónicas de la plataforma continental argentina. Campañas transecciòn BIP "Oca Balda" 1987/88/89. Boletim do Instituto Oceanográfico do Sao Paulo 41 (1/2): 81-94.

Rullier, F. \& L. Amoureux 1979. Annèlides polychètes. Campagne de la Calypso au large des côtes atlantiques de l'Amérique du Sud (1961-1962). Annales de I'Institut Océanographique 55: 10-206.

Salazar-Vallejo, S. \& J. M. Orensanz 1991. Pilárgidos (Annelida: Polychaeta) de Uruguay y Argentina. Cahiers de Biologie Marine 32: 267-279.

Sánchez, M., D. Giberto, L. Schejter \& C. Bremec 2010. The Patagonian scallop fishing grounds in shelf break frontal areas: the non assessed benthic fraction. Latin American Journal of Aquatic Research.
Sanfilippo, R. 1994. Polychaete distribution patterns on Chlamys patagonica of the Magellan Straits. Mémories du Muséum National d'Histoire Naturelle 162: 535-540. Thatje, S. \& A. Brown 2009. The macrobenthic ecology of Straits of Magellan and the Beagle Channel. Anales del Instituto de la Patagonia (Chile) 37(2): 17-27.

Uschakov, P.V. 1962. Polychaetous Annelids of the Families Phyllodocidae and Aphroditidae from the Antarctic and Subantarctic. Biological Results of the Soviet Antarctic Expedition 1955-1958, Exploration of the Fauna of the Seas I (X): 129-189.

Wesenberg-Lund, E. 1962. Polychaeta Errantia. Reports Lund University Chile Expedition 1948-49. Lunds universitets årsskrift 57(12): $130 \mathrm{pp}$. 
